rzy w znacznym stopniu wspierali misje. Wskazał też na potrzeby misjonarzy w czasie prowadzenia misji. Przede wszystkim dominikanie wydawali pieniądze na żywność, odzież, środki transportu, koszty podróży, wynagrodzenie i odzież dla służby, pocztę i opłaty, patenty i papier, zakrystię, ofiary i inne prace zlecone. Z zestawienia wydatków, dokonanego przez autora za lata 1780-1794 oraz 1819-1820 wynika, że najwięcej pieniędzy pochłaniały środki transportu (8930 zł) i wynagrodzenie dla służby (8267 zł).

Książka o. Brzozeckiego Misje ludowe dominikanów prowincji litewskiej 1751-1826 nie pozostawia wątpliwości, że do rąk czytelników trafia wartościowa publikacja. Ogrom pracy, jaki włożył w zgromadzenie materiałów, przeanalizowanie ich oraz omówienie, jest imponujący. Praca dostarcza wiele interesujących informacji. Mam tu przede wszystkim na myśli przebieg dnia misyjnego. Jest to niewątpliwie publikacja, która może w przyszłości posłużyć do analizy porównawczej w przygotowywaniu oraz prowadzeniu misji przez inne zgromadzenia zakonne. Wystarczy chociażby wspomnieć o pracy misyjnej wzmiankowanych już wcześniej misjonarzy św. Wincentego a Paulo.

Całość pracy wzbogacona została dodatkowo ilustracjami, bibliografią oraz wykazem najważniejszych skrótów. Interesującym i wartościowym dopełnieniem publikacji są tabele przedstawiające wykazy: składu zespołu misjonarskiego, miejscowości, w których dominikanie prowadzili misje, osób przyjętych do służby przez zespół misjonarski do pracy oraz ich wynagrodzenie. Na szczególne podkreślenie zasługują również zamieszczone mapy na końcu pracy. Dają one obraz przebiegu misji a zarazem uzmysławiają czytelnikowi ich zasięg.

Agnieszka Wieczorek (Toruń)

\title{
Edukacja historyczna w szkole: teoria i praktyka, red. E. Chorąży, D. Konieczka-Śliwińska, S. Roszak, Wydawnictwo Naukowe PWN, Warszawa 2008, ss. 401
}

rednio co dziesięć lat środowisko naukowe polskich dydaktyków historii wydaje monografię, przedstawiającą aktualny punkt widzenia na problemy związane z szeroko rozumianą edukacją historyczną, która staje się istotnym punktem odniesienia zarówno w stosunku do przeszłości, jak i do najważniejszych wyzwań edukacyjnych współczesności. W ostatnich latach ukształtował się zwyczaj, 
że takie prace naukowe przygotowywane były najczęściej w oparciu na doświadczeniach przedstawicieli z kilku ośrodków akademickich. Tak było w przypadku Dydaktyki historii, red. J. Maternicki, Cz. Majorek, A. Suchoński, (Wydawnictwo Naukowe PWN, Warszawa 1993) czy Wspótczesnej dydaktyki historii: zarys encyklopedyczny, red. J. Maternicki (Wydawnictwo Juka, Warszawa 2004).

Warto w tym miejscu zwrócić uwagę na fakt, że w pierwszej dekadzie XXI w. na rynku wydawniczym ukazało się wiele prac, których autorzy, najczęściej w indywidualnych rozważaniach, prezentowali własne przemyślenia i propozycje dydaktyczne w zakresie różnorodnych problemów dydaktyki historii, będących skutkiem pilnej potrzeby ustosunkowania się środowiska historyków do kolejnych reform edukacji oraz zapotrzebowania środowisk kształcących nauczycieli oraz samych nauczycieli historii. W tym kontekście wymienić można m.in. prace: Alojzego Zieleckiego, Wprowadzenie do dydaktyki historii, Wydawnictwo AVALON, Kraków 2007; Marii Bieniek, Dydaktyka historii: wybrane zagadnienia, Wydawnictwo Uniwersytetu Warmińsko-Mazurskiego, Olsztyn 2009, czy publikację zbiorową pod redakcją Lucyny Kudły i Czesława Nowarskiego pt. Dydaktyka historii jako dyscyplina akademicka wobec wyzwań wspótczesności, Wydawnictwo Naukowe Uniwersytetu Pedagogicznego, Kraków 2008. Wśród licznych propozycji, jakie ukazały się w ostatnim okresie, warto jednak pokusić się o wskazanie tej, która z uwagi na zakres podejmowanych zagadnień, prezentację nowatorskich i systemowych rozwiązań wytyczy nowe kierunki myślenia o współczesnej edukacji historycznej na kolejną dekadę.

Powyższe kryteria niewątpliwie spełnia praca Edukacja historyczna: teoria i praktyka, red. E. Chorąży, D. Konieczka-Śliwińska i S. Roszak, Wydawnictwo Naukowe PWN, Warszawa 2008, będąca efektem przemyśleń i doświadczeń przedstawicieli różnych ośrodków naukowych. Książka napisana jako kompendium zawierające zarys podstawowych informacji teoretycznych oraz propozycji praktycznych rozwiązań dydaktycznych skierowana została do studentów historii, jak i studentów innych kierunków wybierających specjalizację nauczycielską z tego przedmiotu; do początkujących nauczycieli, jak i tych ubiegających się o kolejne stopnie awansu zawodowego, a także do słuchaczy studiów podyplomowych z historii. Mocną stroną tej propozycji jest to, że napisali ją teoretycy i jednocześnie praktycy dla praktyków, tj. historycy, mający doświadczenie wynikające z pracy pedagogicznej nabyte na różnych poziomach edukacji, zarówno z pracy nauczyciela historii, dydaktyka historii, metodologa, historyka historiografii, jaki i egzaminatora pracującego w państwowych komisjach egzaminacyjnych.

Na szerokim tle przeobrażeń, jakie w ostatnich kilkunastu latach przeszła edukacja historyczna, które śmiało określić możemy rewolucyjnymi, autorzy wprowadzają czytelnika w najważniejsze zagadnienia dotyczące wiedzy i kompetencji przyszłych nauczycieli, których opanowania wymagają najnowsze standardy kształcenia. 
Całokształt zagadnień analizują także w odniesieniu do zmian zachodzących we współczesnej historiografii oraz w podejściu do nauk pedagogicznych. Wskazują, że niezwykle ważną nową perspektywą dla edukacji historycznej są zmiany w modelu badań historiografów, którzy, odchodząc od tradycyjnej procesualno-ilościowej analizy naukowej, poszukują obecnie nowych obszarów i metod badawczych, kierując co raz częściej swoje zainteresowanie na odkrywanie nowych aspektów z zakresu historii kultury, antropologii historycznej czy mikrohistorii.

Niezmiernie ważnym dopełnieniem dla procesu kształcenia nauczycieli jest przypomnienie, że spór nad wyższością nauk historycznych nad pedagogicznymi zakończył się fiaskiem dla obu dyscyplin naukowych i współcześnie należy szukać pomiędzy nimi konsensusu. Autorzy wskazują jednak, że wciąż aktualnym i dyskusyjnym problemem są próby określenia proporcji wiedzy historycznej do wiedzy i praktyki pedagogicznej. Najwybitniejszy bowiem historyk w ich przekonaniu nie poradzi sobie z procesem przekazywania wiedzy, kształtowania umiejętności i postaw bez znajomości podstaw wiedzy z psychologii rozwojowej oraz praktycznych zasad pedagogicznych. I odwrotnie, znakomity psycholog i pedagog, wyposażony w wiedzę teoretyczną i doświadczenie praktyczne nie sprosta stawianym wymaganiom bez znajomości warsztatu pracy historyka oraz szeroko rozumianej wiedzy historycznej.

Bezsprzecznym walorem naukowo-poznawczym omawianej monografii jest przejrzystość budowy oraz przemyślana kolejność analizowanych zagadnień, które pozwalają na zapoznanie się z najważniejszymi problemami edukacji historycznej na tle całego systemu edukacji. Student oraz początkujący nauczyciel wprowadzeni zostają w najistotniejsze teoretyczne zagadnienia edukacji historycznej oraz wdrożeni do zaplanowania własnej praktycznej pracy lekcyjnej. Doświadczony nauczyciel uzyska natomiast syntezę nowych aktualnych koncepcji edukacyjnych oraz propozycję konkretnego materiału do zastosowania podczas lekcji, który stać się ma w konsekwencji inspiracją do wprowadzania własnych rozwiązań dydaktycznych. Niezwykle cenne wydaje się wyeksponowanie przez autorów w każdym rozdziale, obok zagadnienia kluczowego, odniesień do dorobku dydaktyków i pedagogów polskich, ale również angielskich i francuskich, oraz do stanu wcześniejszych badań, a także wskazanie najbardziej przydatnych w ich ocenie elementów z tego dziedzictwa i odesłanie do opracowań rozszerzających omawiane dyskusyjne czy kontrowersyjne zagadnienia.

Autorzy podejmują wiele ważnych kwestii, do których zaliczyć możemy m.in. problem wykorzystywania źródeł w edukacji historycznej. Nowa podstawa programowa analizę i interpretację źródeł historycznych, obok chronologii i narracji zalicza do najważniejszych wymagań ogólnych szkolnej edukacji historycznej. Kształcenie kompetencji źródłoznawczych uczniów, dawniej zastrzeżone jedynie dla szkoły 
średniej, współcześnie rozciągnięte zostało na wszystkie etapy kształcenia historycznego. W szkole podstawowej uczeń zdobywa umiejętności dostrzegania, rozpoznawania i nazywania źródeł, w gimnazjum podejmuje próby ich odczytywania, a na poziomie szkoły ponadgimnazjalnej dokonuje samodzielnych poszukiwań, stawiając pytania w zakresie krytyki wewnętrznej i zewnętrznej analizowanych źródeł.

Duże znaczenie zatem dla współczesnej dydaktyki oraz potrzeb edukacji szkolnej ma podjęta przez autorów próba uproszczenia i uporządkowania pojęć dotyczących klasyfikacji źródeł. Klarowny dla ucznia oraz uzasadnionym dla różnych okoliczności edukacyjnych, szczególnie na niższych poziomach edukacji, wydaje się podział źródeł na pierwotne i pochodne. Pierwsze występują w postaci nadanej przez autora (zabytki, eksponaty muzealne, źródła domowe i in.), drugie w formie informacji opracowanej na podstawie źródeł pierwotnych na potrzeby praktyki szkolnej (fragment kroniki Galla Anonima, fragment Deklaracji Niepodległości).

Dużym walorem analizowanej pracy jest skoncentrowanie się autorów, w niespotykanym dotąd zakresie w tego typu monografiach, na praktycznym wymiarze edukacji historycznej. Dołączony do każdego analizowanego zagadnienia wachlarz przykładów praktycznych ułatwia samodzielną refleksję i praktyczne przygotowanie do pracy w szkole. Na podkreślenie zasługuje również perspektywiczny wymiar analizowanych zagadnień. Autorzy analizują wyzwania stojące przed nauczycielem na kolejnych etapach edukacji, a więc podstawowym, gimnazjalnym i ponadgimnazjalnym, ale nakazują mu widzieć siebie jako nauczyciela na tle całego systemu kształcenia. W czasie wprowadzania w kolejne szczeble wtajemniczania akcentują, że nauczanie i wychowanie na każdym etapie kształcenia jest naturalną konsekwencją w stosunku do nauczania i wychowania na poprzednim poziomie kształcenia. Uświadamiają przyszłych adeptów sztuki nauczania historii, że błędy popełnione przez nauczyciela będą miały swoje konsekwencje w kształceniu wychowanków na wyższych poziomach edukacji.

Mocną stroną analizowanego kompendium jest także całościowe pokazanie drogi planowania pracy nauczyciela z zespołem uczniów, od operacyjnego formułowania celów kształcenia bieżącego podczas lekcji, poprzez dobór właściwych metod i środków kształcenia do oceny realizacji założonych celów w aspekcie oceny wewnątrzszkolnej, jaki i oceniania zewnętrznego w postaci systemu egzaminów doniosłych. Słabszym punktem podręcznika są te jego części, które wymagają wsparcia wiedzy historycznej oraz kształtowanych kompetencji przyszłych nauczycieli wiedzą i praktyką pedagogiczną. Może dla podniesienia wartości takiego kompendium w przyszłości, i wzmocnienia rangi rozważań niektórych podrozdziałów, warto byłoby zaprosić do współpracy (konsultacji) pedagoga lub psychologa w celu szerszego pokazania $\mathrm{w}$ jednym kompendium trudności wynikających z konieczności łączenia ze sobą kompetencji z zakresu nauk historycznych oraz pedagogicznych. 
Dotychczasowe podręczniki przygotowują bowiem nauczyciela do pracy w standardowych, czyli w idealnych warunkach szkolnych, kiedy wszyscy uczniowie na równi zmotywowani są do nauki i nie sprawiają nauczycielowi kłopotów wychowawczych. Brak wskazówek oraz odsyłaczy do literatury specjalistycznej, jak ma uczyć nauczyciel w sytuacji nietypowej, z uwagi na brak dyscypliny w klasie czy konieczność zaspokajania szczególnych - indywidualnych potrzeb swoich wychowanków. Chodzi tutaj o potrzeby uczniów uczących się w klasach integracyjnych, ale i także uczniów szczególnie zdolnych, wymagających odmiennych od standardowych metod i technik kształcenia (J. Robertson, Jak zapewnić dyscypline, tad i uwage w klasie?, Warszawa 1998; J. W. Eby, J. F. Smutny, Jak ksztatcić uzdolnienia dzieci i młodzieży?, Warszawa 1998; i in.). Należy zwrócić uwagę, że problematyka kształcenia uczniów o szczególnych potrzebach edukacyjnych dostrzeżona została w polskim prawie oświatowym w latach 70., a w ustawie z 1991 r. i w aktualnym prawie oświatowym jest konsekwentnie rozwijana. W praktyce jednak środki finansowe przeznaczane są jedynie na kształcenie w klasach integracyjnych. Problemu kształcenia niestandardowego (elitarnego dzieci uzdolnionych) władze oświatowe w Polsce nie widzą, ale czy dydaktycy również powinni w XXI wieku zakładać jedynie standardowe modele edukacji historycznej?

Małgorzata Strzelecka (Toruń)

\section{Anna Peck, Konstruowanie historii. Prezentacja i percepcja Polski $w$ amerykańskich podręcznikach akademickich i szkolnych, Wy- dawnictwo Uniwersytetu Jagiellońskiego, Kraków 2010, ss. 199}

$\mathrm{R}$ ecenzowana książka ukazała się nakładem wydawnictwa Uniwersytetu Jagiellońskiego, jej autorka związana z University of North Carolina, Center zajmuje sę prede wszystim problemami związanymi z prezentaj Polski w amerykańskich podręcznikach. Inny obszar jej zainteresowań stanowi sposób postrzegania buddyzmu na obszarach Syberii i Mongolii, pojawiający się w tekstach rosyjskich uczonych i misjonarzy przed 1917 rokiem $^{1}$.

${ }^{1}$ http://www.unc.edu/depts/slavic/people/CSEEES\%20Fellows.html (data dostępu: 14.02.2011). 